\title{
COMMUNISTS, RUSSIA, AND THE IRA, $1920-1923^{*}$
}

\author{
EMMET O CONNOR \\ University of Ulster, Magee College
}

\begin{abstract}
A B S T R ACT. After the foundation of the Communist International in I9I9, leftists within the Socialist Party of Ireland won Comintern backing for an Irish communist party. Encouraged by Moscow, the communists hoped to offset their marginality through the republican movement. The Communist Party of Ireland denounced the Anglo-Irish treaty, welcomed the Irish Civil War, and pledged total support to the IRA. As the war turned against them, some republicans favoured an alliance with the communists. In August 1922 Comintern agents and two IRA leaders signed a draft agreement providing for secret military aid to the IRA in return for the development of a new republican party with a radical social programme. The deal was not ratified on either side, and in 1923 the Communist Party of Ireland followed Comintern instructions to 'turn to class politics'. The party encountered increasing difficulties and was liquidated in Fanuary 1924. The communist intervention in the Civil War highlights the contrast between Comintern and Russian state policy on Ireland, and was seminal in the evolution of Irish socialist republicanism.
\end{abstract}

From 1920 to the end of 1922 , communists in Ireland hoped to offset their acute marginality through the republican movement. During the War of Independence they sought to become the conduit of international red aid to Ireland. Following the truce in July I92I, they looked forward to an accretion of support from disappointed republicans on the conclusion of a peace settlement. With the signing of the Anglo-Irish treaty on 6 December I92I, the Communist Party of Ireland (CPI) adopted a third position. While it found the treaty intrinsically obnoxious, the party also believed that the republican split on the treaty had placed the Irish Republican Army (IRA) under the control of die-hards with a pragmatic social outlook, the type of nationalists most susceptible to Wolfe Tone's dictum: 'if the men of property will not help us they must fall; we will free ourselves with the aid of the large and respectable class of the community - the men of no property'. ${ }^{1}$ Civil war, the communists held, would push the IRA into this traditional separatist fall-back position and transform the fortunes of their tiny party.

From a review of Irish sources, primary and secondary, one would conclude that the CPI was of trivial importance in I922, its policies more green than red,

* I am grateful to the British Academy for subventing research on which this article is based, and to Dr Barry McLoughlin for help with Russian sources.

${ }^{1}$ Workers' Republic, 28 Jan. 1922. Tone, founder of the United Irishmen in I79I, made the celebrated comment in 1796 . 
and its expectations outlandish. Aside from Milotte's hostile monograph, in which the communists are faulted at every turn, accounts of the Civil War ignore or give short shrift to the party. ${ }^{2}$ The prevailing view is that aside from the noted social radicals, Peadar O'Donnell and Liam Mellows, IRA leaders rebuffed CPI overtures and saw no advantage in addressing the social question. ${ }^{3}$ For the most part, the marginality of the CPI cannot be gainsaid, but in other respects a different perspective emerges from British, communist, and Russian sources. A British intelligence campaign to associate the Irish independence movement with Bolshevism was not entirely groundless. ${ }^{4}$ Republicans had sought aid from Moscow during the War of Independence, and it was not impossible that they would do so again in a civil war. The Communist International took a strongly pro-IRA stance, and Soviet Russia gave the CPI a potential far in excess of its size. The CPI came closer to securing a deal with the IRA than has been realized. That it failed was not due exclusively to disinterest on the republican side.

\section{I}

After the foundation of the Comintern in March I9I9, a running battle developed within the Socialist Party of Ireland (SPI) over the question of affiliation to the Third International. The SPI was founded in June Igog and identified with Ireland's foremost Marxist, James Connolly. Connolly had helped to form a workers' militia, the Citizen Army, in I9I3, and led it into the I9I6 Easter rising. His subsequent execution made him a national martyr. The SPI was revived in January I9I7 by William O'Brien and other prominent officers of the Irish Transport and General Workers' Union (ITGWU). O'Brien's circle maintained an ambiguity on the SPI's identity, projecting it on occasion as communist, but generally opposing ties with Moscow. They were also content to let the party function largely as a propaganda platform. Little attention was devoted to organization, and membership probably never exceeded I50. ${ }^{5}$ In September igr9 a soi-disant Bolshevik faction, led by Roddy Connolly, managed to get a resolution passed recommending SPI affiliation to the Comintern. Though not yet nineteen years old, Roddy was enterprising, brash, and impatient, and enjoyed the cachet of being the son of James, and a veteran of the Easter rising. When their rivals regained control and deferred the proposal, the Bolsheviks styled themselves the Workers' Communist Party, denounced the SPI to the Comintern, and got

${ }^{2}$ Mike Milotte, Communism in modern Ireland: the pursuit of the workers' republic since I9I6 (Dublin, I984), is written from a Trotskyist perspective.

${ }^{3}$ Henry Patterson, The politics of illusion: republicanism and socialism in modern Ireland (London, I989), pp. I6-25; Richard English, Radicals and the republic: socialist republicanism in the Irish Free State, 1925-1937 (Oxford, I994), pp. 52-65.

${ }^{4}$ For examples of British propaganda see Richard Dawson, Red terror and green (London, I920), and British Parliamentary Papers, Intercourse between Bolshevism and Sinn Féin, Cmd I326 (London, I92I).

5 Thomas Darragh [Roddy Connolly], 'Revolutionary Ireland and communism', Communist International, June-July ig2o. 
Connolly and Eadhmonn MacAlpine accredited as delegates to the second world congress of the Comintern, held in Petrograd and Moscow in July and August 1920. ${ }^{6}$

Since March igig the Comintern had made a few favourable references to the Irish national struggle, but it was the second world congress that marked the real beginning of communist policy on Ireland. ${ }^{7}$ Connolly and MacAlpine arrived with a report intended to secure backing for an Irish section of the International. Their paper opened with a short paragraph on Ireland's strategic position as a flashpoint adjacent to the heart of British imperialism and the homeland of a diaspora spread throughout the empire and the USA. In greater detail it anticipated a party engaging in various theatres of activity, such as trade unions and the co-operative movement, as well as with elements of the national struggle. Taking a purely tactical view of nationalism, it described the IRA as both 'potentially white guards' and fertile ground for red propaganda, and suggested that Ulster would be less complicated territory for communists as its anti-nationalist proletariat was more amenable to class politics. Implying that success in Ireland would be contingent on the British proletariat, the document looked forward to the closest co-operation with the Communist Party of Great Britain (CPGB), leading to a federated workers' republic of Britain and Ireland. ${ }^{8}$

Developments at the congress encouraged Connolly and MacAlpine to invert the emphasis in their report, to highlight the geo-political significance of the national revolution over the complexities of party-building in domestic politics. First, the congress was instilled with renewed hopes of the revolution being carried into western Europe as the Red Army advanced on Warsaw. Secondly, it endorsed V. I. Lenin's belief that the Comintern should function as the general staff of a world party, directing national policies according to a global strategy. Thirdly, it was indicative of Comintern interests that items on Ireland in the congress news bulletins for delegates dealt entirely with the independence struggle, noting with implicit satisfaction that 'The revolutionary movement in Ireland continues unabated. ${ }^{\text {9 }}$ Finally, the congress appointed a commission to examine 'theses on the national and colonial questions'. As president of the commission, Lenin distinguished between oppressor and oppressed nationalisms, and urged communists to ally with national movements in the colonies, provided they were revolutionary and broadly sympathetic. Ditching their ambivalence on nationalism, the Irish delegates adopted a more robust anti-imperialist line, on two grounds. 'Any force',

\footnotetext{
${ }^{6}$ Milotte, Communism, pp. 36-48. No more was heard of the Workers' Communist Party after the second world congress.

7 Stephen White, 'Ireland, Russia, communism, post-communism', Irish Studies in International Affairs, 8 (I997), pp. I55-6I.

8 Report on the situation in Ireland, E. MacAlpine, Roderic J. Connolly, 7 July I920, Russian State Archives for Social and Political History, Moscow (Rossiiskii Gosudartsvennyi Arkhiv Sotsial'noPoliticheskoi Istorii, hereafter RGASPI), MSS 5/3/58I-I/8.

9 Bulletin for delegates to the second congress of the Communist International, 5 July, I6 July I920, RGASPI, MSS 489/I/54-33/34.
} 
Connolly told the commission, 'that tends to hinder the free play of the imperialist states against the developing world revolution must be encouraged and actively supported by the Communist International'. He did not portray Irish republicans as socially radical. Rather would they pragmatically 'avail themselves of every weapon against British imperialism', and communists in Ireland could be empowered if the Comintern made them the vehicle of aid to the separatists. ${ }^{\mathbf{1 0}}$

The Irish headed home with approval for a party and for their tactics, only to encounter setbacks in both respects. On 20 October Erkki Veltheim, a Comintern agent, was arrested in London with a coded letter in his possession saying: 'Impossible to go successfully [to] Ireland to start party etc or negotiate Irish Republican mission without money. Present using $£ 3$ oo sent to Irish unions whilst awaiting news. "11 To add to Connolly's embarrassment, the Russian Press Review had already announced the donation of $£ 300$ to Irish railwaymen dismissed for blacking the transport of British munitions. Tom Johnson, secretary of the Irish Labour Party and Trade Union Congress, denied receipt of any money from Russia, Moscow tendered no explanation, and Dr Pat McCartan, later the Irish republic's envoy to Russia, informed the Dáil secretariat that Connolly and McAlpine had squandered the £30o. More plausibly, McCartan concluded from his Russian sojourn that Connolly and MacAlpine had been promised $£ 3$, ooo to activate the 200 strong Citizen Army, which was virtually moribund since i9i 6. According to McCartan, Connolly's failure to influence the Citizen Army led the Comintern to regard him as 'too lazy to be a Communist'. ${ }^{12}$

If the Comintern endorsed the policy of channelling support to Ireland through Irish communists, the Russian People's Commissariat for Foreign Affairs, Narkomindel, had another agenda. Between I9I8 and I922, its officials in London cordially received representations on matters such as trade and fraternal exchanges with Russia from Tom Johnson and William O'Brien, the very people that Connolly was denouncing as sham socialists and striving to oust from the leadership of the SPI. ${ }^{\mathbf{3}}$ Narkomindel officials were no more discriminate in their relations with republicans. In May I9I7 the supreme council of the Irish Republican Brotherhood (IRB), deeming itself to be the government of the republic, appointed McCartan as its envoy to Russia, where 'the representatives of the workmen, soldiers, and sailors had referred to Ireland in a friendly resolution; and we believed they would soon be in power'. ${ }^{14}$ McCartan's mission was redirected to the USA, when republicans decided that President Woodrow Wilson's talk of peace

10 The Communist International in Lenin's time: workers of the world and oppressed peoples unite! Proceedings and documents of the second congress, 1920 (New York, I99I), pp. 248-9.

11 Walter Kendall, The revolutionary movement in Britain, IgOo-I92I: the origins of British communism (London, I969), p. 255.

$12 \mathrm{~J}$. Anthony Gaughan, Thomas Fohnson, I872-1963: first leader of the Labour Party in Dáil Éireann (Dublin, I980), p. I53; Johnson to W. N. Ewer, 2I May I92 I, RGASPI, MS 495/89/9-3; for McCartan in Russia see reports on Russia from mission, Feb.-June i92 I, National Library of Ireland (NLI), McCartan papers, MS I7682. $\quad 13$ Voice of Labour, 9 Feb. I9I8; Gaughan, Johnson, p. 442.

14 Patrick McCartan, With de Valera in America (Dublin, I932), pp. 2-3. 
based on self-determination sounded more promising, but after the Bolshevik revolution agents of the two pariah states opened contact in America. A mutual recognition treaty was drafted and in October 1920 the republic loaned \$20,ooo to Russia. Connolly's hopes of exploiting this situation came to nothing. On I7 November he and MacAlpine submitted credentials to the Dáil secretariat affirming that 'the Executive Committee of the Third International has decided to assist by all means in its power the National Revolutionary movement in Ireland'. Though the credentials gave them authority to speak for the Comintern alone, they claimed to be the 'only accredited agents empowered to negotiate for the initiation of diplomatic negotiations' with Russia. The secretariat replied that it would deal exclusively with the Russian government. ${ }^{15}$ While the Russians were keen on a treaty in 1920, President Éamon de Valera hesitated, apprehensive about the impact on the bigger prize of winning recognition from the USA. When he finally decided to send McCartan to Moscow, the Soviets had gone cold on ties with the republic, for fear of jeopardizing trade negotiations with Britain.

McCartan arrived in Moscow on I4 February to assess the value of a propaganda office in Russia and, he hoped, conclude trade and recognition treaties. Connolly met him off the train and escorted him to the Comintern's Hotel Lux. McCartan appreciated the significance of being lodged in the Lux, rather than one of the Narkomindel hotels: the presence of an Irish diplomat embarrassed his hosts. Foreign commissar G. V. Chicherin received him promptly, and enquired after the Citizen Army, but refused to entertain the sale of munitions to the IRA. Though McCartan was assured by Santeri Nuratova, his contact in Narkomindel, that Chicherin 'was not in a position to know' about arms sales, and that McCartan would be put in touch with 'the man who had charge of that department', Nuratova was arrested within weeks and shot as a British spy. McCartan expected Narkomindel to be less paranoid and more sympathetic once the Anglo-Russian trade agreement had been signed on i7 March. He gave no credence to its provision for an end to Soviet propaganda against Britain, and possibly underestimating Chicherin's hostility to Russian involvement with illegal political operations abroad, or his influence - advised Dáil Éireann that the kernel of the problem was Narkomindel's belief that the Irish would compromise on their demand for independence. ${ }^{\mathbf{1 6}}$ In June he was more pessimistic. Convinced that the Russians regarded the Irish struggle as purely nationalist and of little use to themselves, he left for the west empty handed.

By early I92 I the Irish communists had decided that it was not feasible to operate legally, and reformed the Communist Groups, set up originally just before the second Comintern congress. Modelled on the conspiratorial IRB, the Communist

${ }^{15}$ Undated document, without a rubric, I920, RGASPI, MS 495/89/3-24; Arthur Mitchell, Revolutionary government in Ireland: Dáil Érreann, 1919-1922 (Dublin, 1995), pp. 189-92; Dáil Éireann papers, National Archives of Ireland (NAI), MS DE 2/II9.

${ }^{16}$ Aino Kuusinen, Before and after Stalin: a personal account of Soviet Russia from the Ig20s to the 196os (London, 1964), p. 51, recalls Chicherin as vehemently opposed to Comintern involvement with illegal activities abroad. 
Groups aimed to cultivate influence within the executives of the IRA, IRB, ITGWU, and SPI. ${ }^{17}$ They were given a fillip when Séamus Robinson, the leftish commandant of the IRA's 3rd Tipperary Brigade, asked Connolly to help procure arms in Germany for the Brigade. Connolly duly embarked for Berlin with Billy Beaumont, an ex-British army officer. Billy's brother, Seán, was prominent in the Communist Groups and the Irish language movement, and was briefly a judge in the Sinn Féin courts. ${ }^{18}$ This unusual unilateral action by an IRA brigade came unstuck and led to Connolly's suspension from the Groups. The Beaumonts joined a more successful IRA smuggling operation in Germany in the autumn. Shortly beforehand, Seán had travelled on to Moscow, where he tried to impress Mátyás Rakosi, the Comintern secretary, with claims that the 3 rd Tipperary Brigade was unhappy with IRA policy, and that the Brigade adjutant with two members of the Communist Groups had made contact with an officer of the German general staff who offered to sell them 'three submarines, and a large quantity of minenwerfer and anti-tank guns'. ${ }^{19}$ He alleged that since the truce Sinn Féin was drifting towards compromise in the peace talks, and the implacables were ready to resume the war and seeking fresh allies on the left. Soviet aid to the IRA would give the Communist Groups 'a tremendous influence with the active revolutionary forces'. Rakosi declined to receive him, and the Communist Groups had disintegrated by the new year. ${ }^{20}$ The IRA did succeed in bringing two arms ships from Germany to Ireland in November I92I and April 1922, and also purchased the 2,ooo ton steamer, City of Dortmund, for regular smuggling of small quantities of munitions. ${ }^{21}$

Connolly meanwhile had attended the third Comintern congress in Moscow in June and July I92I, where he discussed the Irish situation with Lenin and received the Comintern's approval to form a party. ${ }^{22}$ In September he led his faction to capture the SPI. He was then elected president of the party and would be its motor force for the next seventeen months. For most of that period he would also edit the party's organ, the Workers' Republic. Party strategy depended on the outcome of the Anglo-Irish negotiations, and had an unreal quality before the treaty. Connolly expected that the twin problems of Ulster and allegiance to the crown would be resolved to the satisfaction of the broad majority of republicans; extreme Sinn Féiners would reject any compromise and gravitate to the

\footnotetext{
${ }^{17}$ Report to Kobietsky for the ECCI, RGASPI, MSS 495/89/Io-2/4a; report on the work of the Irish Communist Groups, RGASPI, MSS 495/89/2-30/33; report of the CPI to the ECGI, Oct. I92I to Oct. I922, RGASPI, MS 495/89/16-44.

18 Éamon Ó Ciosáin, An t-Éireannach, 1934-1937: Nuachtán Sóisialach Gaeltachta (Dublin, 1993), pp. 67-70, II 7 .

19 The IRA had an established contact with Major Hassenhauer of the Orgesh, a secret right wing organization. Brian P. Murphy, Fohn Chartres: mystery man of the treaty (Dublin, 1995), pp. 48-9.

${ }^{20}$ Report on the work of the Irish Communist Groups, RGASPI, MSS 495/89/2-30/33; Mac Neill [pseudonym of Beaumont] to Rakosi, 3 Sept. I92I, RGASPI, MS 495/89/8-2 ; F. E. Smith to Rakosi, 3 Dec. I92I, RGASPI, MSS 495/89/8-40/4I.

${ }^{21}$ Emmet O Connor, 'Waterford and IRA gun-running, 1917-1922', Decies: Fournal of the Waterford Archaeological Historical and Society, 57 (200I), pp. I8I-93. $\quad{ }_{22}$ Milotte, Communism, pp. 45-6.
} 
communists, but peace would prevail. ${ }^{23}$ He therefore proposed a conventional strategy for the SPI, derived from theses on party organization adopted at the third Comintern congress. The party should concentrate on economic and industrial affairs, building nuclei in trade unions and factories. While he allowed that nuclei would be created subsequently in the Citizen Army and the IRA, he made no reference to the national struggle. He also argued that the SPI be reorganized and expanded, in collaboration with reformists if necessary, before being turned into a communist party. ${ }^{24}$ The majority of members disagreed with him. On 28 October the SPI became the CPI and an application for affiliation to the Comintern was dispatched to Moscow. An accompanying report claimed that the party had I20 members and appealed for $\AA_{\mathrm{I}, 740}$ to fund two organizers and a press. ${ }^{25}$ Connolly remained unhappy with the party's composition and potential. He deemed the membership too small to influence the unfolding industrial unrest that would rattle the economy for the next two years, though that did not prevent him subjecting the Dublin branch to three purges before the Civil War. ${ }^{26}$

Meanwhile, the CPGB held that the peace talks would break down on the issue of allegiance to the crown and split Sinn Féin. ${ }^{27}$ During the truce Cathal Brugha, the republic's minister of defence, had consulted Tom Johnson and William O'Brien on enlisting assistance from the CPGB in the event of renewed hostilities. O'Brien arranged for him to meet the British communist leader Willie Gallacher, who arrived in Dublin on 6 December with a tip-off that a treaty had been signed on British terms. Gallacher pressed Brugha to have the returning Irish signatories arrested and to persuade his colleagues to adopt a socialist programme. 'Gallacher', said Brugha, 'you are always welcome in Ireland, but we do not want any of your communism. '28

The Workers' Republic went to press on 6 December with an editorial headed 'War! What for? ... If it is Peace we certainly are elated.' Connolly had been coy about his prognoses for the peace talks in Ireland; perhaps the better to feign a tone of shocked betrayal when the time came. On i7 December a suitably outraged Workers' Republic published a manifesto predicting 'civil war and social hell ... if [the treaty] is accepted'. It objected especially to the treaty's provision for dominion status for the Free State. Connolly was convinced in Trotsky's thesis that imperial rivalry would bring Britain and the United States to war.

THE EMPIRE IS ROCKING! It is being broken and crushed in India, destroyed in Egypt, and will soon be torn asunder by a proletarian uprising in England itself. Above all, the hostile attitude of America threatens to seal its doom. Faced with the greatest crisis in its history it foregoes its claim to rule unchallenged in Ireland, thereby effects a compromise with the weaker spirits among the republicans, and immensely strengthens its position in the coming inevitable conflict with America.

${ }^{23}$ Workers' Republic, 29 Oct., I7 Dec. I92I.

24 Ibid., I6 Sept., 2I Oct. I92 I.

25 CPI to the ECCI, 9 Nov. I923, RGASPI, MSS 495/89/8-5/I2.

26 Report of the CPI to the ECCI, Oct. I92 I to Oct. I922, RGASPI, MSS 495/89/I6-40/I45.

27 Workers' Republic, I7 Dec. I92I.

28 Gaughan, fohnson, pp. I9I-2. 
'The people and fighters of Ireland must stand resolutely for de Valera and Brugha', declared the Workers' Republic, 'however reactionary either may be as regards the workers' aims'. So assured was Connolly of anti-treatism as the hinge of strategy, that the CPI ignored Comintern policy for the next twelve months. On 18 December the Executive Committee of the Communist International (ECCI) directed that in view of the reverses experienced by the European working class, affiliates should pursue united fronts with reformists. The enormous controversy generated among communists by the directive by-passed Ireland. In Ireland, declared the Workers' Republic on 4 February, the Labour Party's neutrality on the treaty, above all, rendered the option impossible.

\section{I}

The CPI did not entirely neglect social unrest, and became involved briefly with unemployed agitation in January 1922, and with evicted tenants prior to the Civil War. $^{29}$ But it regarded even the numerous workplace soviets declared in 1922 in response to demands for wage cuts as small beer compared with the prize of shaping the forthcoming republican revolution. ${ }^{\mathbf{3 0}}$ The abiding problem was how to influence the IRA. The Labour Party could not be persuaded to accept the CPI into affiliation, or oppose the treaty. ${ }^{31}$ Republicans ignored an offer of six of the eight pages of the Workers' Republic, appeals for offensive action, and advice to devise a social programme. ${ }^{32}$ In March the CPI abandoned hope of drawing support from the Citizen Army and formed its own military section. ${ }^{33}$ Connolly knew it was a feeble gesture.

The broader military picture was more encouraging. Dáil Éireann had ratified the treaty on 7 January by 64 to 57 votes. One week later a provisional government was set up under Michael Collins, pending the enactment of the Free State. While the provisional government began enlisting an army in Dublin, British troops were evacuating barracks all over the twenty-six counties and local IRA units were taking their place. On 26-7 March 223 delegates representing some 80 per cent of IRA volunteers convened in defiance of a provisional government proclamation and effectively withdrew their allegiance from the protreaty regime. When the chairman of the IRA's military council, Rory O'Connor, was asked: 'Do we take it that we are going to have a military dictatorship, then?', he replied: 'You can take it that way if you like. ${ }^{, 34}$ On I2 April Connolly told

\footnotetext{
${ }^{29}$ Report of the CPI to the ECCI, Oct. I92I to Oct. I922, RGASPI, MSS 495/89/I6-40/I45.

${ }^{30}$ For industrial unrest see Emmet O Connor, Syndicalism in Ireland, I9I7-1923 (Cork, I988), pp. $9^{6-\mathrm{I} 67 .}$

31 Officially the Labour Party and Trade Union Congress were neutral on the treaty. In practice the leadership supported the Free State. The CPI saw no contradiction in opposing the Labour Party and seeking affiliation to it. $\quad{ }^{32}$ Milotte, Communism, pp. 55-7.

33 Report of the CPI to the ECCI, Oct. I92 I to Oct. I922, RGASPI, MSS 495/89/i6-40/I45.

34 Florence O'Donoghue, No other law: the story of Liam Lynch and the Irish Republican Army, 19I6-1923 (Dublin, I954), pp. 334-5; Dorothy Macardle, The Irish republic (London, I968), pp. 6I4-I8.
} 
Moscow: 'it is becoming more apparent that the [IRA] controls the entire situation, that the 80 ,ooo armed [IRA] men are the real dominant factor', adding that some members of the IRA executive were calling themselves 'social republicans' and that the 'IRA in large numbers are drifting towards us'. Through leading the IRA the CPI had the possibility of 'jumping from 200 to 20,000 members in the course of the next six months' ${ }^{35}$ This was certainly making a mountain out of a molehill. The IRA's roll call exceeded I00,00o, but it is doubtful if its field strength reached a twentieth of that number. ${ }^{36}$ The IRA executive contained one CPI member, Peadar O'Donnell, who failed to persuade even his sympathetic colleagues to confer with the party, as they were reluctant to be identified with the 'reds' ${ }^{37}$ The IRA did promulgate an agrarian programme on I May, instructing local commandants to seize specified land and property for distribution to the people. The manifesto was largely the work of an agrarian radical, P. J. Ruttledge, and it was never applied or championed by anti-treatyite politicians. ${ }^{38} \mathrm{Still}$, it seemed to the CPI that events were moving in the right direction. 'Civil War necessary' read the headline in the Workers' Republic on 6 May.

On ro May I922 eight members of the Anglo-American Colonial Group of the ECGI convened in the Hotel Lux to prepare the groundwork for the Comintern's first major public pronouncement on Ireland. Two thought that the treaty would liquidate the national struggle, and cited the general strike against militarism called by the Irish Trade Union Congress on 24 April. ${ }^{39}$ The others disagreed, and approved a lengthy review which recommended unconditional backing for republicans on the grounds that independence was a pre-requisite of a workers' republic, that most workers supported independence, and that the Irish struggle weakened the British empire. The review none the less ended in a conclusion diametrically opposed to Connolly's, that the national struggle precluded 'a big Communist movement in Ireland for some time'. ${ }^{40}$ Evidently satisfied with the Colonial Group's analysis, the ECCI laboured to tap the well springs of Irish patriotism. Two papers were drafted. A message 'To the workers and peasants of Ireland' deplored the Collins-de Valera pact, entered into on 20 May in an effort

${ }^{35}$ Report to the Comintern on the Irish party, R. Connolly, Berlin, 12 Apr. 1922, RGASPI, MSS $5 / 3 /$ $58 \mathrm{I}-9 / \mathrm{I} 7$.

${ }^{36}$ The IRA had a paper strength of II2,650 in July I92I, and enlistment increased after the truce. O'Donoghue, No other law, p. 334. However, it is estimated that only 3,00o to 5,00o volunteers were active during the War of Independence, with another 50,000 involved in some secondary or marginal way. Mitchell, Revolutionary government, p. 275. The IRA numbered almost I3,80o volunteers in August i924. IRA executive report, Moss Twomey papers, Io Aug. I924, University College, Dublin, Archives (UCDA), MS P69/180(25).

${ }^{37}$ Borodin to the ECGI, interview with delegates from the Irish party, I5 July 1922, RGASPI, MSS 495/89/I3-6/23; McLay to the ECCI, 3I Aug. 1922, RGASPI, MSS 495/89/12-39/46.

${ }^{38}$ C. Desmond Greaves, Liam Mellowes and the Irish revolution (London, I988), pp. 313-I4.

${ }^{39}$ Nominally, the strike was in protest at all militarism, in a vain attempt to prevent civil war. The communists denounced it as anti-IRA.

40 Anglo-American Colonial Group of the ECCI, minutes, Io May 1922, RGASPI, MSS 495/72/ 2-85/95. 
to avoid conflict between the pro- and anti-treaty wings of Sinn Féin in the forthcoming general election. The second paper was 'Appeal to the Irish workers', which heaped ethnic flattery atop the conventional jargon:

The glorious traditions of the Celtic genius are now handed over to the care of the Irish working class ... WORKERS OF IRELAND! The Emerald Isle of the poets can only smile again in the bloom of freedom under the Red Flag of Labour. It can only be truly emancipated by the workers organised into a class conscious party of the proletariat. ${ }^{41}$

The eventual manifesto, addressed to the workers of Britain and Ireland, was mercifully more prosaic:

It is only the young Communist Party of Ireland which has the courage and the determination to point to the right path and to say: 'It is only after the yoke of the English imperialists has been shaken off that the struggle against the Irish exploiters will have any chance of success!' ...

The attitude of the proletarian majority of the Irish Republican Army is a proof that the Irish Communist Party, notwithstanding its short existance, is on the right path and represents the will of the Irish working class. ${ }^{42}$

The CPI had already condemned the Collins-de Valera pact-Collins himself repudiated it on I4 June, two days before the polling - and urged workers to give first preference votes to republicans and second preferences to the Labour Party in the elections. ${ }^{\mathbf{4}}$

By contrast, the Russian government maintained its neutrality on Ireland. In February I922 Tom Johnson and an official of the provisional government had met Leonid Krassin, Soviet trade attaché in London, to discuss the establishment of Russo-Irish economic links. While nothing came of the meeting, Krassin said that his government would welcome 'close political and commercial relations' with the new Irish state. ${ }^{\mathbf{4 4}}$

\section{I I}

On the outbreak of the Civil War on 28 June, Connolly and some twelve CPI men with weapons training joined the IRA's Dublin Brigade. After eight days of fighting, the Free State army controlled the capital, some communists and the two most promising social republicans, O'Donnell and Mellows, were interned, and the IRA had begun its ignominious retreat. ${ }^{45}$ Connolly went to London to arrange for the printing of the Workers' Republic through the CPGB. The CPI's relations with the CPGB had never been easy. The latter had given space in its organ, the Communist, to critics of the CPI leadership, and maintained contact

\footnotetext{
41 To the workers and peasants of Ireland, RGASPI, MSS 495/89/IO4-IO2/IO5; appeal to the Irish workers, RGASPI, MSS 495/89/I-2I/24.

42 Workers' Republic, I July I922.

${ }^{43}$ Ibid., I7 June i922. $\quad{ }^{44}$ Department of the Taoiseach files, NAI, MS S482.

45 Though the Free State did not come into being until 6 December I922, the term was already in use to describe the provisional regime and its army.
} 
with Labour Party and republican leaders without consulting the CPI. On 8 July the Communist heartily endorsed CPI policy in a front page editorial, though it had its doubts about an IRA victory: 'Collins ... knows that whatever befalls, the British power is at his back and that it far outweighs the Republicans.'

On I5 July Connolly and George McLay, the CPI treasurer, were introduced to the impressive figure of Mikhail Borodin, 'a tall, well-built, black-haired, swarthy-complexioned' Russian. Widely travelled and an excellent linguist, Borodin had been working for the Comintern in Britain since March under the pseudonym George Brown. ${ }^{46}$ In a long and frank debriefing, Connolly and McLay assured him that the IRA would sustain a guerrilla war, compelling a British intervention which would destroy the Free State. Borodin hit them with blunt materialism:

It is my firm opinion that they will crush the Republicans ... It is really laughable to fight the Free State on a sentimental plea. They want a Republic. What the hell do they want a Republic for? ... There are two military sections fighting - one is very strong and the other is very weak. One say Ireland should be fighting for prosperity. The other other one is absolutely void of interest in any [such] matters.

Despite pleas that it would probably be a waste of time, Borodin insisted that, if only for propaganda purposes, they present a social programme to the republicans. ${ }^{47}$ Together they drafted a document intended to give republicans a popular appeal. The manifesto demanded state ownership of heavy industry, transport, and the banks; land redistribution; an eight-hour working day; joint councils of workers, trade unions, and the state to regulate working conditions; municipalization of public services; rationing of housing and abolition of rents; maintenance for the unemployed at trade union rates; and universal arming of workers. ${ }^{48}$ A version appeared in the Workers' Republic on 29 July, and the paper adjusted its editorial line to concede that people saw little material advantage in opposing the Free State and emphasize the need for republicans to 'attract the masses'.

As the Free State army fanned out from Dublin, only Munster remained under IRA control. On 26 July Connolly and Seán McLoughlin hastened to Fermoy, in the heart of the fraying 'Munster Republic', and pressed IRA Chief of Staff Liam Lynch to establish a civilian government in Cork and apply their programme. By all accounts Lynch's insistence that guerrilla tactics alone would win the war brought the initiative to a sterile conclusion. ${ }^{49}$ However, over the next few weeks there were a series of remarkable developments. Lynch briefed his staff on the discussions next day. McLoughlin, a trenchant critic of republican vacuity on social issues, rejoined the IRA as a commandant. Probably in mid-August Borodin sent his secretary, J. T. Murphy, and Arthur MacManus, chairman of

${ }^{46}$ J. T. Murphy, New Horizons (London, I94I), pp. 88-9.

47 Borodin to the ECCI, interview with delegates from the Irish party, I5 July I922, RGASPI, MSS 495/89/13-6/23.

${ }^{48}$ Report of the CPI to the ECCI, Oct. I92I to Oct. I922, RGASPI, MSS 495/89/16-40/I45.

${ }^{49}$ Milotte, Communism, pp. 59-6I; Greaves, Mellows, p. 359. 
the CPGB, to interview republican and communist activists in Dublin. On a mission similar to that of Connolly and McLoughlin at Fermoy, they met 'two of the Chiefs of Staff of the IRA' in a Dublin suburb and signed a joint document for submission to their respective executives. ${ }^{\mathbf{5 0}}$ Murphy and MacManus briefed Moscow that a programme close to that of the CPI had received an 'excellent' reception in republican quarters. If endorsed by the IRA executive, a political department was to be formed, leading to the creation of a new republican party. Opposition from de Valera was anticipated, but as long as the Civil War lasted, the British rapporteurs expected de Valera to remain subordinate to the IRA executive. The report then offered a sensational assessment: 'If by every possible means military, economic, political help can be rendered the I.R.A. ... the future of the Republican forces is one with ours.' Murphy and MacManus worried none the less about backsliding in their absence, doubted the ability of the CPI 'in spite of the favourable conditions under which it operates', and advised the Comintern to start a new party. ${ }^{51}$

Connolly was understandably chuffed with the turn of events. Borodin was an important man. In I923 he was appointed Comintern emissary to China and Soviet legate to Sun Yat-sen, and engineered in the Kuomintang the kind of communist-nationalist alliance he had had in mind for Ireland. The 22 August 1922 found Connolly in Berlin. He was definite about the IRA's commitment, less so about the communists.

All the arrangements are made on the Republican side as far as communications, having a captain for the ship etc. We have to get a ship, reconstruct it so as to carry arms, \& get a crew, \& buy the arms. The republicans are sending a man, who is already in London, with Io.ooo pounds, as preliminary expenses. As well, their Executive guarantees/I have the guarantee in writing/to pay to us half the cost of any shipment of arms as soon as same is landed in Ireland, \& the remainder as soon afterwards as is possible. Borodin suggests that the Executive Comintern contribute half the expenses in every case ...

For details etc it is necessary I go to Moscow as there does not seem to be anyone here capable or willing to tackle this big proposition. ${ }^{52}$

Connolly did travel to Moscow, but at this point the evidence becomes opaque. ${ }^{\mathbf{5 3}}$ The CPI or CPGB revealed no inkling of moves afoot other than an editorial in the Workers' Republic on 2 September calling for a republican social programme, and a more exceptional and pointed article in the Communist on I6 September, which implied that a moment of truth approached: 'To De Valera the lesson

50 Murphy, New Horizons, pp. I84-6. Murphy uncertainly recalls one of the IRA chiefs as Michael Mallin and says he kept insisting he was a soldier and not a politician. Mallin was a Citizen Army commandant, executed in May i9i6. Murphy does not name the other man. It is possible that he confused Mallin with Ernie O'Malley, who had his headquarters in August 1922 in the house of a

Catholic curate in a Dublin suburb. $\quad{ }^{51}$ Untitled report, RGASPI, MSS 495/89/I3-83/84.

${ }^{52}$ Connolly to Luise, 22 Aug. I922, RGASPI, MS 495/89/I2-36. Luise, an official of the German party, acted as a liaison between the CPI and Moscow.

${ }^{53}$ ECGI to CPI, I9 Sept. I922, saying 'Comrade RG is here representing your party', RGASPI, MS $495 / 89 /$ I2-53. 
should be by now clear - Either with the proletariat against the Free State Bourgeoisie or with the Free State and its bourgeoisie against the proletariat.' In December Murphy was told that his correspondence on Ireland had 'for some reason or other' never arrived in Moscow, though two fragments of one lengthy memorandum survive in the archives, suggesting that the Comintern did wish to say yea or nay to material aid to the IRA. ${ }^{\mathbf{5 4}}$ It could not have helped that the last town under IRA control had been abandoned on I I August, or that Borodin was arrested in Glasgow in mid-September and spent six months in prison. ${ }^{\mathbf{5 5}}$

While there is no other evidence of an IRA response to the discussion with Murphy and MacManus, Ernie O’Malley, effectively second in command to Lynch and director of the IRA's northern and eastern divisions, enquired of a colleague on I2 August: 'Can you ... put me in touch with official Labour ... I am not in touch with I.C.A. [Irish Citizen Army] or Roddy Connolly's crowd ... It is important that we should ulitise such resources as the I.C.A. and the Communist Party. ${ }^{\mathbf{5 6}}$ And on 18 August O’Malley asked Mellows - a prisoner since 30 June for his views on the political and military way forward. Mellows immediately recommended the sale of the City of Dortmund to release $£$ Io,ooo for the purchase of arms. Days later, in consultation with O'Donnell, he drafted two detailed memoranda advising the formation of a republican civil government with a programme similar to that in the Workers' Republic on 29 July. ${ }^{57}$ In late August two IRA agents were dispatched to Germany. ${ }^{58}$ The provisional government's interception and publication on 2I September of Mellows's 'Notes from Mountjoy' marked the zenith of CPI hopes. The party told Moscow that it had won three prominent converts - Mellows, O'Donnell, and Joe McKelvey - who would build a mass base for social republicanism, and counselled the IRA against peace talks with the provisional government. As late as 18 November it was predicting the imminent collapse of the Free State under the weight of its military expenditure. ${ }^{59}$ Instead, Mellows and McKelvey were to fall before a Free State firing squad on 8 December in reprisal for the assassination of Seán Hales, TD.

Whether an arms deal would have affected IRA policy is a matter of speculation. O'Malley urged Lynch repeatedly to implement Mellows's proposals, and his senior colleagues revised the Democratic Programme - Dáil Éireann's social manifesto adopted in I9I9 - and Ruttledge's May Day manifesto of I922. ${ }^{60}$ Coincidentally, Irish republicans based in Glasgow made similar appeals for a social policy. ${ }^{\mathbf{6 1}}$ The chief of staff however, had no time for party politics. He was currently

${ }^{54}$ Murphy to the Comintern, I2 Dec. I922, RGASPI, MS 495/89/II-I5.

${ }^{55}$ Murphy, New Horizons, p. 186.

${ }^{56}$ UCDA, Sighle Humphreys papers, I2 Aug. 1922, Pio6/rg64. I am obliged to Brian Hanley for this reference. $\quad{ }^{57}$ Greaves, Mellows, pp. 362-9; English, Radicals and the republic, p. 53.

${ }^{58}$ Robert Briscoe, For the life of me (London, I958), pp. I83-4; Greaves, Mellows, p. 374.

${ }^{59}$ Report of the CPI to the ECGI, Oct. I92I to Oct. I922, RGASPI, MSS 495/89/I6-40/I45; Workers' Republic, 28 Oct. to I8 Nov. 1922.

${ }^{60}$ Ernie O'Malley papers, O'Malley to Lynch, 3 Sept. I922, UCDA, MS Pr7/a/56, O’Malley to Lynch, 24 Sept. I922, UCDA, MS Pi7a/57.

${ }^{61}$ Ernie O’Malley papers, letters, Sept. I922, UCDA, MS Pi7a/I59; Greaves, Mellows, p. 374. 
resisting demands from de Valera to convene the IRA executive, which had not met since I5 July, knowing that 'Dev' wanted a truce. On I3 September de Valera gave the IRA three options: accept sole responsibility for the struggle, pass the authority to the anti-treaty Dáil, or agree to a compromise between the two. Faced with the loss of political support, the executive assembled on I6-I7 October and called on de Valera to form a government. No consideration was given to exploring links with the communists. ${ }^{62}$ It hardly mattered that Mellows was made minister for defence in de Valera's phantom cabinet. The objective now was to salvage an honorable peace from the jaws of defeat.

\section{V}

The fourth world congress of the Comintern in Petrograd and Moscow in November and December I922 formally ended the communist courtship of the IRA, and brought the CPI under direction from Moscow through the supervision of the CPGB. In I923 the prominence of Scots like McLay, MacManus, Bob Stewart, and Tom Bell in Irish affairs, and the number of speakers from Glasgow at its propaganda meetings, would earn the CPI the soubriquet 'the Communist Party of Scotland'. ${ }^{63}$ The congress determined that parties in the colonies should adopt 'dual tasks', organizing in both national revolution and class struggle. A lengthy resolution of solidarity with Ireland's 'valiant fighters against British Imperialism' was adopted, but privately, Nikolai Bukharin, deputy leader of the Comintern, insisted that the republican movement would be defeated, and reprimanded Connolly and McLay for neglecting class politics and not asserting the independence of their party. ${ }^{64}$ On I3 $_{3}$ December an ECCI resolution on Ireland instructed the CPI to concentrate on activity among the proletariat and adopt a position of moral support towards republicans. In vain, J. T. Murphy pleaded that moral support would not impress the republicans and make it harder to win members from the IRA. ${ }^{65}$ Back in Dublin at least, the CPI offered no protest.

Characteristically, Connolly swung from one extreme to the other. In January he called on republicans to accept military defeat, launch a new party, take the oath of allegiance, and enter Dáil Éireann; and on prisoners to sign the 'prison promise', undertaking not to resume hostilities against the state. ${ }^{\mathbf{6}}$ For some the political somersault was too much too soon. For critics of Connolly's previous emphasis on the national question, it seemed glib and arrogant. He had already incurred resentment within the party for alleged egotism, sarcasm, refusal to do 'spade work', and affecting the manner of a bourgeois officer on his inscription into the

\footnotetext{
62 Frank Aiken papers, executive meeting, I6-I7 October I922, minutes, UCDA, MS PIo4/I262(2)PIO4/I262(9).

${ }^{63}$ Seán MacEntee papers, 'Notes on communism in Saorstát Éireann', UCDA, MS P67/523(5), p. 9.

64 Workers' Republic, 6 Jan. I923; McLay to Luise, report on the situation in Ireland, 26 June I924, RGASPI, MSS 495/89/27-Io/I4.

65 Murphy to the Comintern, I2 Dec. I922, RGASPI, MS 495/89/II-I5.

66 Workers' Republic, 6-20 Jan. I923.
} 
IRA in June. ${ }^{67}$ On $20-\mathrm{I}$ January the CPI hastily convened its first annual congress, with the intention of removing him. He was not re-elected to the central committee and replaced as editor of the Workers' Republic. ${ }^{68}$ A second congress on I8 February adopted the Comintern's directive to 'turn to class', with one dissentient. Tom Bell was present to advise the congress, and pass on $£ 90$ from the Comintern. ${ }^{69}$

Paradoxically, Bukharin's prediction that the republican movement would be broken by military defeat made the CPI reluctant to reject militarism. On I7 February the Workers' Republic deplored talk of peace and urged republicans to 'fight on', pending a political victory. A major shift in policy followed the IRA's ending of hostilities on 24 May. The CPI published a draft programme which projected national independence as an outcome of, not a means towards, a social revolution; and envisaged united front tactics with labour bodies and acceptance of Free State political institutions. ${ }^{\mathbf{7 0}}$ Yet the problem of relations with republicans persisted. In the August general election the party divided on its attitude to Sinn Féin candidates. The central committee wished to offer them conditional support. Connolly convened an aggregate meeting of members which favoured unconditional support. The dispute provoked resignations and prompted an ECCI investigation. In October Arthur MacManus recommended the liquidation of the party. ${ }^{71}$ Membership had fallen to around seventy, and recent recruits were judged to be more republican than communist. The party was heavily in debt, and limping along on a quarterly subvention of $£ 75$ from Moscow. At all levels it was riven by personal squabbles. ${ }^{72}$ Crucially, the Comintern had already decided that Jim Larkin was the best man to lead communism in Ireland, and was aware that Larkin would not work with any party except one of his own creation. The CPI was dissolved on 26 January I924, and Moscow later recognized Larkin's Irish Worker League as its Irish affiliate. ${ }^{73}$

Two of the major questions of Comintern history concern its relations with national sections, and with Soviet foreign policy. ${ }^{74}$ During the 'third period' the

${ }^{67}$ White and O'Leary to the ECCI, 26 Feb. 1923, RGASPI, MSS 495/89/22-35/38.

${ }^{68}$ Report of the first annual congress of the CPI, 20-I Jan. I923, RGASPI, MSS 495/89/2I-I/5. Twenty-three members attended the congress, another twelve were in prison, fourteen were with the IRA, and a further fifteen apologized for non-attendance.

${ }^{69}$ Resolution endorsing the Comintern directive of policy ... passed by the CPI, RGASPI, MS 495/ 89/2I-I ; resolution of the presidium of the ECCI on the Irish question, RGASPI, MSS 495/38/7-235/ 236; White and O'Leary to the ECCI, 26 Feb. I923, RGASPI, MSS 495/89/22-35/38; A. B. F. White and J. J. O'Leary to Luise, I8 Feb. I923, RGASPI, MS 495/89/22-2.

${ }^{70}$ Workers' Republic, 9 June 1923.

${ }^{71}$ Report by MacManus and the politbureau of the CPGB, in Oct. I923, RGASPI, MSS 495/38/ 7-236/24I. $\quad{ }^{72}$ CPI report from George McLay, RGASPI, MSS 495/89/22-74/76.

${ }_{73}$ Emmet O Connor, 'Jim Larkin and the Communist Internationals, I923-1929', Irish Historical Studies, 3I (May 1999), pp. 357-72.

${ }^{74}$ Kevin McDermott and Jeremy Agnew, The Comintern: a history of international communism from Lenin to Stalin (London, 1996), p. xx. 
Comintern established a dominance over the former, and became subordinate to the latter. The situation was more unstable in the early I920s, when the Comintern was still attempting to assert its authority and not all communists agreed on how the interests of the Russian state and international revolution should be reconciled. For the most part, the CPI was a subservient party; it was usually the case that the smaller the affiliate, the greater the dependency on, and loyalty to, Moscow. Yet the negative impression that that conveys needs to be qualified. Communism in Ireland acquired significance and coherence from the myth - and the money - of the Comintern. On one point on which it felt strongly, relations with the anti-treaty forces, the CPI was prepared to pursue a unilateral policy. On other matters, members believed that Comintern directives made sense. The Comintern emerges as authoritarian on general policy. The fourth Comintern congress demanded an abrupt and radical change of course from the CPI, irrespective of circumstances in Ireland. On the other hand, Moscow was patient and flexible on the application of policy. There is a disparity too in the Comintern's handling of the Irish. Through regular communication and agents it sought to keep itself informed on and sensitive to their difficulties. But setbacks were attributed to failures in application, not to problems of policy.

The Comintern's pro-active, pro-republican approach to Ireland contrasted sharply with Narkomindel's detachment after i920. However, on the crucial issue of rendering material aid to the IRA, the ECCI ultimately conformed to Soviet foreign policy. This may have been coincidental, as the looming fourth congress had its own rationale for restricting help to republicans. At the same time there is evidence that the ECCI was embarrassed by MacManus and Murphy's appeal for aid in the autumn of I922. Aino Kuusinen, then a Comintern apparatchik and wife of Otto, secretary of the Comintern, cites the controversy over the 'Zinoviev letter' in I924 as a turning point in the International's techy relations with Narkomindel. Chicherin demanded that the Comintern cease to involve itself in clandestine activities, and 'certain types of secret work' were transferred to the Fourth Department, the Red Army intelligence service. A brief liaison was established between the Fourth Department and the IRA in the late I920s, until exposed by Scotland Yard. ${ }^{75}$

The reasons for the communists' pro-IRA stance were manifold. In Moscow, opinions differed on whether nationalism amounted to an obstacle or an opportunity, but all agreed that conflict against the British empire was to the benefit of Soviet Russia. In Ireland, the IRA was seen by the CPI as a short-cut to power. While communists cited their numerical weakness to justify neglect of class conflict, it was also true that most had a background in militant nationalism - a typical feature of communist parties in colonial countries. Though the Comintern determined party policy, in prescribing support for the IRA it was pushing at an open door. Even after the 'turn to class' in I923, a sizable number of members

\footnotetext{
75 Kuusinen, Before and after Stalin, p. 51 ; Raymond W. Leonard, Secret soldiers of the revolution: Soviet military intelligence, I9I8-I933 (Westport, CT, I999), pp. 99-Ioo.
} 
drifted back to the former policy of alignment with republicans. Most communists shared with social republicanism a perception of the IRA as plebeian in character and sympathy, and a belief that a workers' republic alone could guarantee national independence. By October I923 Connolly and two other CPI officers had accepted appointments as Sinn Féin organizers. ${ }^{\mathbf{7 6}}$

Finally, the history of the CPI provides further evidence that social republicanism during the Free State era was not due exclusively to an internal revision of IRA policy. Communists prompted the evolution at almost every step. ${ }^{77}$ Their intervention nearly bore fruit in the autumn of I922. Ironically, it was a step too far for the Comintern.

${ }^{76}$ CPI, report to Oct. I923 from Apr. I923, RGASPI, MSS 495/89/22-74/76.

77 For critiques of social republicanism see Patterson, The politics of illusion, pp. 26-68; and English, Radicals and the republic, passim. For communism and the IRA after I923 see O Connor, 'Jim Larkin', passim. 